\section{Areas of mentoring needs of novice and preservice teachers}

\author{
Nilgün Dağ ${ }^{a}$, Mehmet Hayri Sarı ${ }^{b}$
}

\author{
Received: 30 June 2017 \\ Revised: 14 August 2017 \\ Accepted: 08 Sept. 2017 \\ ISSN: 1307-9298 \\ Copyright (C) IEJEE \\ www.iejee.com
}

DOI: 10.26822/iejee.2017131892

\begin{abstract}
This research on mentoring phenomenon aims at putting forth the areas of mentoring need for the novice and preservice teachers. This study exhibits a pattern consisting of qualitative research model and takes as a basis the case study approach. Criteria sampling technique was used in the research due to reasons peculiar to the research. The research was conducted with primary teachers with one to five years of experience in his/her occupation as well as candidate teachers who haven't started service yet. The data was collected through interviews with novice and preservice teachers. Content analysis method was used in the analysis of the data. As a result of the research, it was found out that both novice and preservice teachers need mentoring on pedagogically significant matters.
\end{abstract}

Keywords: Mentee, mentor, mentoring, novice teacher, preservice teacher.

\title{
Introduction
}

Mentoring, a subject of comprehensive academic studies today, has been first described by Homer in lliad. We think that the basic reason behind why the history of mentoring dates so back is recognition of the value of gaining experience within the framework of a masterapprentice relationship. As a matter of fact, when one wished to learn something on anything in ancient times, it was adequate just to take their place as apprentice for someone. The method of learning available in those times was just "to find someone who knew better and to learn from them" (Dag, 2011, p. 2). Master-apprentice relation was considered the most effective way of learning. Although not as much as in those times, occupational knowledge and skills in several countries of the world and in Turkey are today being provided within the framework of that relationship in several different sectors.

Some researchers interpret mentoring as the equivalent of master-apprentice relationship in today's terminology ${ }^{1}$. Mentoring is a learning partnership between a more experience person and a less experienced person in occupational context (Searby \& Tripses, 2012, p. 3). In that partnership relationship, the mentor is a person undertaking entire responsibility for development of the mentee in a way compatible with the corporate culture $\mathrm{s} /$ he is affiliated to, and his/her becoming an effective and productive employee in the corporation. In other words, the source of information is a Socratic questioner. The mentee is the person receiving psychosocial support from a senior and experienced mentor through career (Bakioglu, Gogus, Ulker, Bayhan \& Ozgen, 2015, p. 2).

The vast majority of the fresh teachers require assistance/support in the process of acquisition and reinforcement of knowledge, skills, values and norms. It is also known that many solve problems they may encounter through trial and error or through modeling or imitation. No doubt it is more desirable to overcome those problems or conditions absence of which is evidently felt in a conscious and aware manner by getting professional support instead of having a random solution within their natural course. As a matter of fact, the point reached at education in Turkey as of today is just a great loss of quality.

The ranking of Turkey in international examinations such as PISA, PIRLS, TIMSS has somewhat attracted attentions to teacher education; and the need for qualified and professional education brought up mentoring on Turkey's education agenda. As a matter of fact, in the $19^{\text {th }}$ National Education Council held in 2014, mentoring within the framework of a more structured practice for those new to the teaching occupation was highlighted as a necessity. Mentoring is an individualized professional development process constituting a basis to supporting of teachers and their qualified preparation to their occupation. The process is not just guiding by the mentor of development

\footnotetext{
"This study has been delivered as a speech in "International PAEDEIA Conference: European Symposium Young Teachers as Change Agents" arranged in Gazi University Faculty of Education between 19 to 23 October 2015.

a Mersin University, Faculty of Education, Division of Classroom Instruction Education, Mersin / Turkey E-mail:dagnilgundag@gmail.com

${ }^{b}$ Corresponding author: Nevsehir Hacı Bektas Veli University, Faculty of Education, Division of Classroom Instruction Education, Nevşehir / Turkey E-mail: mehmethayrisari@gmail.com
}

'Although mentoring is perceived as a master-apprentice relationship, it is different in some aspects. Although both has a condition of imbalance due to experience, the power is with the master in master-apprentice relationship, in contrast to mentoring where the power is not with the mentor at all times. It is the liability of the mentor to balance the "power" factor to emerge between the mentor and the served (Bakioglu et.al.., 2015, p. 3-4). Besides, there is a mentoring relationship based on mutual respect, trust and professionalism in addition to open-mindedness and modesty in foundations of the mentoring relationship. Master-apprentice relationship, however, involves a relationship based on unilateral transfer of experience. For that very reason, mutual benefit is not as intense as in the mentoring relationship. In the master-apprentice relationship, unilateral communication and learning is prioritized. 
in pedagogical terms of the teacher willing to get or in need of service. It is also a practice involving more than just the pedagogic guidance of, or educational partnership/friends of the served with, the mentor. Mentoring is not only a joint process which the mentor and the mentee think together and learn together but also one in which the served structures his/her educational experiences in his/her own personal teaching profile. This research aims at putting forth the areas of mentoring need for the novice and preservice teachers.

Business world has for long been one of the first implementation societies in terms of mentoring. Among common themes in the business world are development of counseling programmes for new executives who has been determined to have a potential to climb to senior positions through team counseling and interactive group counseling. As to architecture and engineering, they are among technical fields dealt with through mentoring. Mentoring in architecture is used in recognition of expectations of the employer from and the potential of the new recruit. In engineering, however, it summarizes career continuity whereby newly recruited engineers are first apprentices, then colleagues, then counselors themselves (assisting apprentices in developing career) and finally sponsors (focusing on wider organizational needs) (Buell, 2004, p. 57-8).

One of the disciplines to deal with through mentoring is education. Since 1980s, mentoring constitutes the basis of preparation and orientation programmes for teachers, in other words, of support for new/fresh teachers/mentees. Mentoring is somewhat the process of "individualized professional development" aiming that the new people/disciples come out successfully from their first experiences, describe their teaching life, and establish professional relationships based on dialogue and thought (Ginkel, Verloop, \& Denessen, 2015, p. 1-2). The process provides personal and professional guidance to the inexperienced teachers who have just started the job. Not only advance, development and professionalization of the teacher is ensured in their occupational life, but also contributions are made on matters such as elevation of their sense of personal satisfaction, improvement of their creativity, reinforcement of their communication skills and fortification of their occupational credits (Bakioglu et. al., 2015, p. iii). Without suspicion, mentoring also has an effect to support the professional development of the serving mentor. Consequently, it is a bilaterally useful process.

The mentoring is a process of partnership whereby the mentor and the mentee share, question and structure together the knowledge and experiences of the service receiver. The mentors, however, need to avoid catches such as forcing their own styles or leaving the other party too much free in the process. Because, today mentors and mentees are expected to be "co-thinkers" and "colearners". Mentors should form the mentoring process as "pedagogical structuring" sphere/area/field instead of building it as co-thinking. Because novice teachers will, in that process, have the possibility to restructure their teaching experiences and to place such experiences into their personal teaching theory (Ginkel et. al., 2015, p. 1-2).
The literature comprehensively agrees that mentoring is useful in a series of contexts and in terms of some different. Mentoring seems among the most effective methods of the youth enhancing their self-confidence and helping reach their potential. Also it has been considered that it is vitally important in terms of successful socialization in corporate life. As a matter of fact, when 150 senior executives of the biggest companies of the US were asked in late 1990s about the significance of providing mentoring to new employees, 57 percent of them replied officially or unofficially that this was "extremely significant", and 39 percent replied that it was "somewhat significant" (Buell, 2004, p. 57).

The most significant stage of the mentoring process is the process of mentor election and match-up of the mentor and mentee to get service. There are different programmes for mentor election from strict criteria to no condition at all. However, several experts recommend adoption of strict election procedures. It is thought that competence in teaching should be taken into consideration in the process of election rather than personality traits, management style and coaching skills. Thus, it is a serious matter by whom the mentor is to be elected. The election can be made by not only school principals but also local education authorities or the new teacher him/herself. The satisfaction of the mentor is vitally important for him/her to be ready for future service as mentor for novice teachers. The next item after election of the mentor is the match-up of the mentor and the mentee. The match-up business is considered a significant element of effective counseling since it is about matching different traits such as literature, grade level, field, age, gender, personality styles and geographical proximity (Nasser-Abu Alhija \& Fresko, 2014, p. 163-4).

The biggest difficulty encountered in mentoring relates to finding adequate and appropriate time to have the mentors and the mentees to get service meet. Among the probable reasons of that problem are excessive workload not allowing any free time to the counselor, contradicting educational plans, mentors and mentees not working in the same school, and lack of monetary concessions and professional encouragements for mentors to invest in mentees. As a result, mentoring is, in several cases, rarer than desired and in general results in irregular conduct of mentoring at post-school hours, which in turn has adverse effects on development of a relationship based on confidence and empathy between the mentor and the mentee (Nasser-Abu Alhija \& Fresko, 2014, p. 164-5).

The question what the areas of mentoring are have arisen the interest and curiosity of some experts. Vonk (1995; as cited in: Nasser-Abu Alhija \& Fresko, 2014, p. 165) has found out that the mentoring should be in compliance with the following three main fields about development of the mentees: Pedagogic, emotional, and ecologic. Mentors provide assistance in pedagogic terms by watching the classes, providing feedback, modeling, discussing instructions, assisting lesson plans and helping analyze the homework and success of students, provide support in emotional terms by improving the feelings of self-value and self-confidence, by reassuring, and providing encouragement and compassion in their 
communications and interactions with their colleagues and parents, and assist in ecological terms for orientation to the local school culture.

Wechsler et. al. (2010) have found out that the most common mentoring activity is in pedagogic terms, yet the research by Andrews \& Quinn (2005) has revealed that the mentees get the biggest support about assistance with school policies and procedures, personal and emotional support, class management, resources and materials, and the least support about education and curriculum (as cited in: Nasser-Abu Alhija \& Fresko, 2014, p.165).

The mentor has a series of roles such as a parent figure, problem solver, builder, recommendation giver, supporter, educational model, coach or guide. In addition, they are required to struggle with the ways of thinking of the mentees to improve their self-competences and to prepare them to the actual world of education. In this context, mentoring is a multi-dimensional process involving emotional support and professional socialization in addition to pedagogic guidance (Leshem, 2014, p. 262).

To summarize the results of the researches on mentoring;

1. Mentoring process ensures several benefits both for the mentor and the mentee in individual, occupational and career development terms.

2.Although mentoring programmes of different countries have some aspects in common, some differences may also be observed.

3. The need to mentoring shows and increase and the areas and subjects where mentoring is needed diversify.

Most of the researches submitted and summarized above has been conducted abroad. In Turkey, however, it can be said that there are practices in parallel with mentoring practices in training teachers, although not under the name of mentoring. The implementation works in schools of undergraduate teacher education programmes of Faculties of Education (courses of School Experience and Teaching Practices) are sort of mentoring practices. Similarly, the practice of guiding/counseling teachers commissioned to provide guidance to newly appointed teachers can be considered some sort of a mentoring practice. Nevertheless, we cannot say that there is a mentoring system in Turkey in a professional sense. It is obvious that teachers need the support/channeling of a mentor in various subjects in the first years of the job. In this context, the purpose of this research is putting forth the areas of mentoring need for the novice teachers and $4^{\text {th }}$ grade undergraduate students. The research addressed the following questions:

1. In relation with novice teachers;

1.1. What is the condition in appointment of counselors?

1.2. What are the subjects they may require counseling?

1.3. What are their opinions on the adequacy of the undergraduate teacher education they had received?

1.4. What are the subjects they need support?
1.5. Who and which are the people and entities they seek satisfaction in the subjects they need support for?

2. In relation with the preservice teachers;

2.1. What are their opinions on the adequacy of the undergraduate teacher education they receive?

2.2. What are the subjects they may require counseling?

2.3. What are the subjects they may need guidance for when they first start their job?

2.4. Who and which are the people and entities they'd seek satisfaction in the subjects they may need support for?

\section{Methodology}

\section{Design of the Study}

This research used qualitative research model and employed case study approach. Case studies can be conducted with either qualitative or quantitative approach. The purpose of both approaches is to put forth results regarding a certain case. In qualitative researches, case study relates with intensive studying of a case. Factors regarding a condition are investigated in a holistic approach with a focus on how they influence and are influenced by the concerned condition (Yıldırım \& Simsek, 2008, p. 77).

The condition in research is the fields where primary teachers and candidate primary teachers who have not yet completed their undergraduate teacher education require mentoring. The data gained with the research is applicable for only participants subject to the case study, and limited to their personal opinions and experiences. The research seeks an answer to the following fundamental question: "What are the fields where novice teachers with five years of experience in their occupation and preservice teachers who have not yet completed their undergraduate teacher education require support?"

\section{Participants}

The study followed the path of selection of people that can become a rich source of information instead of random sampling and the technique of criteria sampling, a method of purposeful sampling, was used. The criterion is 1-5 years of professional seniority for novice teachers, and having attended the school experience and teaching application courses for preservice teachers. Professional seniority has been set as 1-5 years for primary teachers since that is the most critical period for a new teacher in his/her effort to remain in the job due to the problems experienced in the first years of teaching (Veeman, 1984). It was also noted if participants accepted interview and were willing to participate.

The research has been realized in the educational year 2015-2016 with 11 novice teachers attending professional development seminars in Nevsehir provincial center and 9 preservice teachers who has attended field experience and student teaching experience course. Data on the participants have been given in Table 1 .

Of the 11 novice teachers negotiated, 8 are female and 3 are male. The teacher with the lowest professional seniority has 1 year and the teacher with the highest 
professional seniority has 5 years. Of the 9 preservice teachers participating in the research, 6 are female and 3 male students.

Table 1. Descriptive particularities of the participants.

\begin{tabular}{lllllllllllll}
\hline Code name & FT1* & FT2 & MT1* & FT3 & FT4 & MT2 & MT3 & FT5 & FT6 & FT7 & FT8 \\
\hline $\begin{array}{l}\text { Professional } \\
\begin{array}{l}\text { Seniority } \\
\text { (Year) }\end{array}\end{array}$ & 4 & 4 & 4 & 2 & 5 & 5 & 1 & 4 & 1 & 2 & 2 \\
$\begin{array}{l}\text { Undergraduate } \\
\text { Students }\end{array}$ & FS1** & FS2 & FS3 & FS4 & FS5 & MS1** & FS6 & MS2 & MS3 \\
\hline
\end{tabular}

*FT1: Female Teacher 1; MT1: Male Teacher 1

** FS1: Female Student 1; MS1: Male Student 1

\section{Instruments of the Study}

The data of the research have been collected with semistructured open-end interviews with the participants. Researchers had their own independent preliminary investigations on the interview questions, and having discussed the interview questions they revealed as a result of the preliminary investigations in the focus group meetings lasting approximately 2 hours, they answered final questions. Researchers put forward the interview questions from their personal observations, examination of the national and international field literature, classroom experiences, school experiences as well as their observations and experiences in the teaching practice course. One of the interview questions were presented to three specialists, one a teacher and two pedagogs, and shaped in line with the criticisms and suggestions received. 5 questions and parallel drilling questions were asked to the novice teachers; and 4 questions and parallel drilling questions were asked to the preservice teachers. The questions to the novice teachers in the interviews are as follows:

1. How old is your professional life?

1.1. Where did you serve?

1.2. For how long?

2. Was a counseling teacher appointed in the first year of your occupation to assist you?

2.1. About which subjects did the appointed teacher help you?

2.2. If not, would you rather have had a counseling teacher to support you?

3. Do you think that the professional knowledge and skills you acquired throughout your undergraduate teacher education is adequate?

3.1. Why?

3.2. In which subjects do you fill inadequate?

4. Are there any subjects you need support in your professional life?

4.1. Which subjects?

5. From where, which institution or by whom should such support you needed in the first years of the job be provided?

6. Ultimately do you have anything to add?

Questions for the preservice teachers are as follows:

1. Do you think that the professional knowledge and skills you acquired in your undergraduate education until now are adequate?
2. In which subjects do you need support considering your experience in the schools you went for internship in teaching application and school experience courses?

3. Do you think that there are subjects you need support in your prospective professional life?

4. From where, which institution or by whom should such support you will need when you start your professional life be provided?

5. Ultimately do you have anything to add?

\section{Procedure}

The interviews were realized on voluntary basis and recorded using a tape recorder, and all of the allowed recording of the interviews via a tape recorder. A chatting style interview approach was adopted in the conversations. Interviews with novice teachers have been realized in an empty classroom determined in on-the-job training course schools early in the semester of the teachers. The shortest interview lasted for 7 minutes 10 seconds and the longest for 11 minutes 18 seconds. The interviews with preservice teachers were realized in the study offices of the researchers on a day and at a time suitable for both researchers and participants. The shortest interview lasted for 6 minutes 15 seconds and the longest for 13 minutes 16 seconds.

Purposeful sampling was used to increase the validity of the study, and data from interviews were reported in detail in the form of direct quotes. Confirmation investigation was held to enhance the trustworthiness of the study. Researchers have conducted a preliminary examination of two weeks in relation with interview records independently; and found out codes and themes. The number of agreements and disagreements among coders have been determined, and the reliability of the research has been calculated using the formula of Miles and Huberman (1994) (Reliability = agreements / agreements + disagreements). The ratio of co-codings to each other is nearly 90 percent. Themes emerged as a result of the preliminary study were discussed, evaluated and a consensus was reached in the focus group meetings lasting 60 to 90 minutes for two weeks. The themes acquired by the researchers were re-coded by another researcher specialized in the field and gained results were compared.

The data have been analyzed the content analysis method. The data were coded in the first stage of the 
analysis. At the second stage, themes were found that can explain in general and collect under certain categories the data in view of the codes emerged. Data have been arranged and described in accordance with the codes and themes at the next stage. The findings were interpreted at the last stage.

Then, 58 Word pages (a total of 31 Word pages for primary teachers, and 27 Word pages for candidate primary teachers) of data has been acquired in total from the voice recordings in the interview. The answers of the participants to the interview questions at the first stage of analysis have been transferred to computer environment, interview questions were analyzed for content; the themes and patterns reached were associated with the experienced phenomenon and explained, opinions that can be included under the same theme were gathered and visualized. Research findings were supported with direct quotes.

\section{Results}

\section{Results related to Novice Teachers}

Results on the Condition of Appointment of Counselors

Within the scope of the first sub-problem of the research, answer was sought for the question "What is the counseling teacher appointment condition for novice teachers in the first year of their profession?". The answers of the teachers to questions were grouped under two themes: (1) Groups for which counseling teacher has been appointed and (2) groups for which no Counseling teacher has been appointed. It is seen that sub-themes emerge under those themes regarding the condition of assisting or not of the appointed counseling teacher, and requesting or not of a counseling teacher if not appointed already (Figure 1).

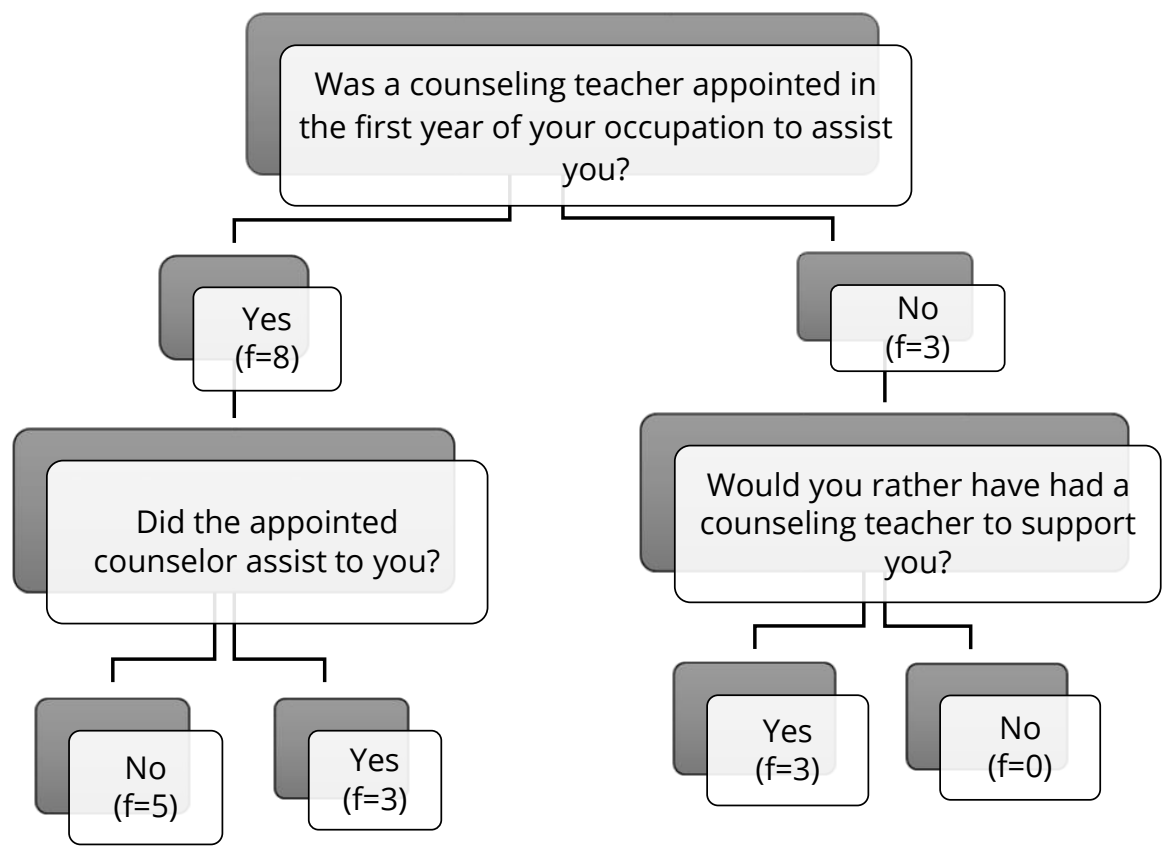

Figure 1. Condition of appointment of counseling teacher for novice teachers.

Figure 1 shows that counseling teachers have been appointed to 8 of 11 novice teachers in contrast to the remaining 3 for whom no counseling teacher has been appointed. 5 of the 8 teachers for whom counseling teachers have been appointed have expressed that they had no help from the counseling teacher, and 3 that they had the necessary assistance and support. The 3 primary teachers who told that no counseling teacher had been appointed to assist them professionally also indicated that they needed assistance of a counseling teacher. Some quotations from novice teachers in relation with the condition of appointment of counseling teachers for them in the first years of their profession are as follows:

FT1: (...) Was appointed on our first appointment. On which subjects did the appointed teacher help you? Now there is that. The teacher assigned to us when we were first appointed was told to help us about teaching classes, about our teaching their classes or about documents. None of those happened... As far as I can tell, those are only formalities.

MT3: (...) No, not assigned. Would you rather have had a guiding/counseling teacher to support you, if not already? Yes, I would.

\section{Findings on the Subjects that require Counseling}

An answer was sought to the question "What are the subjects novice teachers require counseling for in the first years of their profession?" in the second sub problem. The answers of the teachers to questions were evaluated within two themes: (1) Subjects where groups with counseling teacher help novice teachers; (2) Subjects where groups without counseling teacher are in need (Figure 2). 
The subjects for which primary teachers with a Counseling teacher received guidance are class management; parent visits, special education, guidebook use, utilization of the class book, approach to students, regulation and document works. The subjects which novice teachers without a counseling teacher are in need are; class management, time management, educational planning, paying attention to individual differences, approach to students, united class management, educational principles, methods and techniques, utilization of the class book, administrative works, eschool utilization, planning of social activities and not being able to come to terms with students.

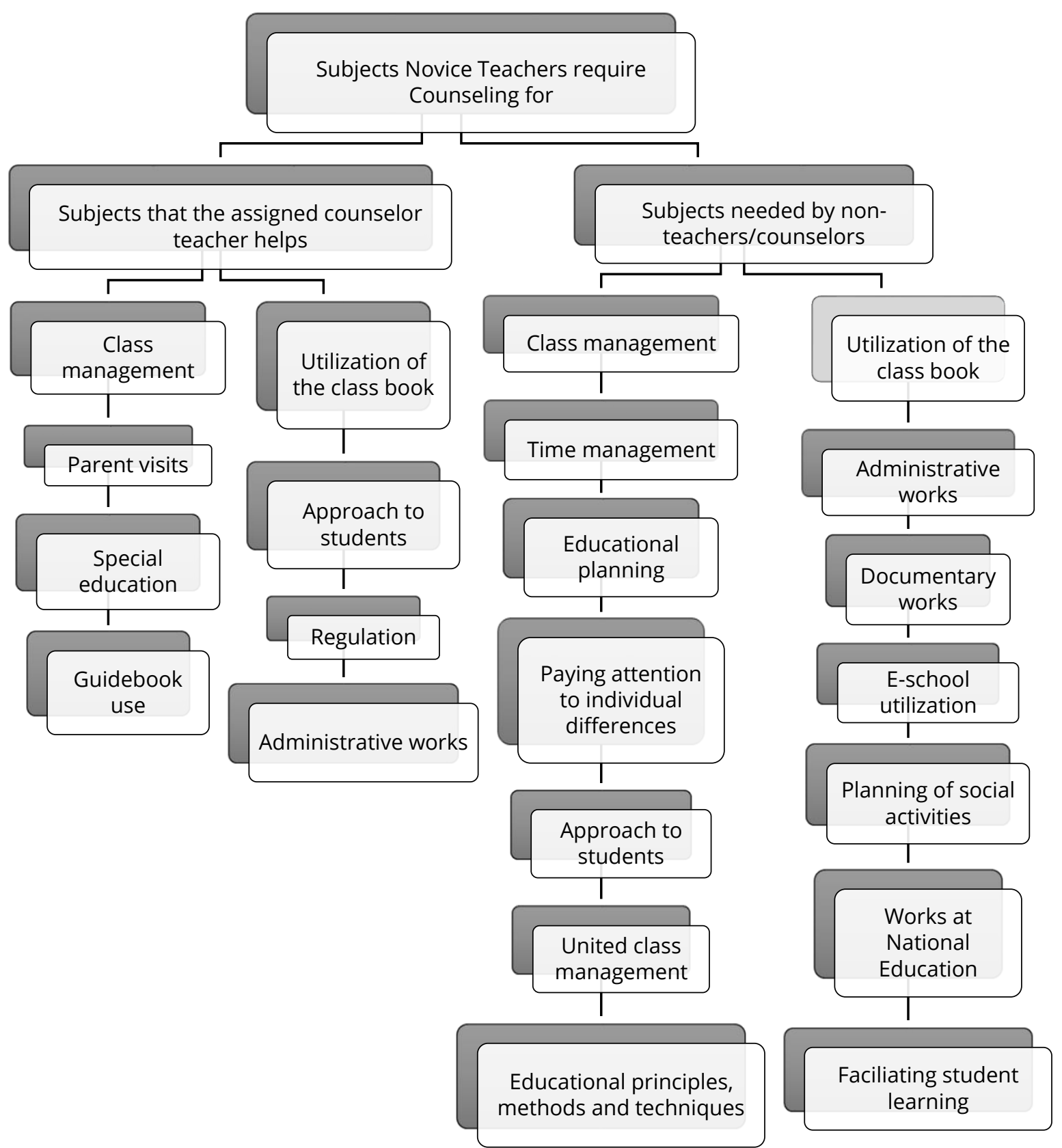

Figure 2. Subjects novice teachers require counseling for.

Subjects which novice teachers with and without Counseling teachers feel lack for are "class management, utilization of the class book, administrative and document works and approach to students". Some of the expressions of the novice teachers with regard to the subjects they need guidance for in the first years of their profession are as follows: 
FT2: (...) This procedure is particularly about regulation. Then class management. (...) How parent visits are made, even he came with me too. (...)

FT3: (...) On that matter, for example, the 40-minute course, that planning and programming of subjects is so important, I didn't know that.

Findings regarding Adequacy of Undergraduate Teacher Education
Within the scope of the third sub-problem of the research, an answer was sought for the question "Do novice teachers serving between years 1 to 5 of their profession see their undergraduate teacher education adequate?". The answers of the teachers to the question were grouped under three themes: (1) Those considering it partially adequate, (2) those considering it inadequate and (3) subjects considered inadequate.

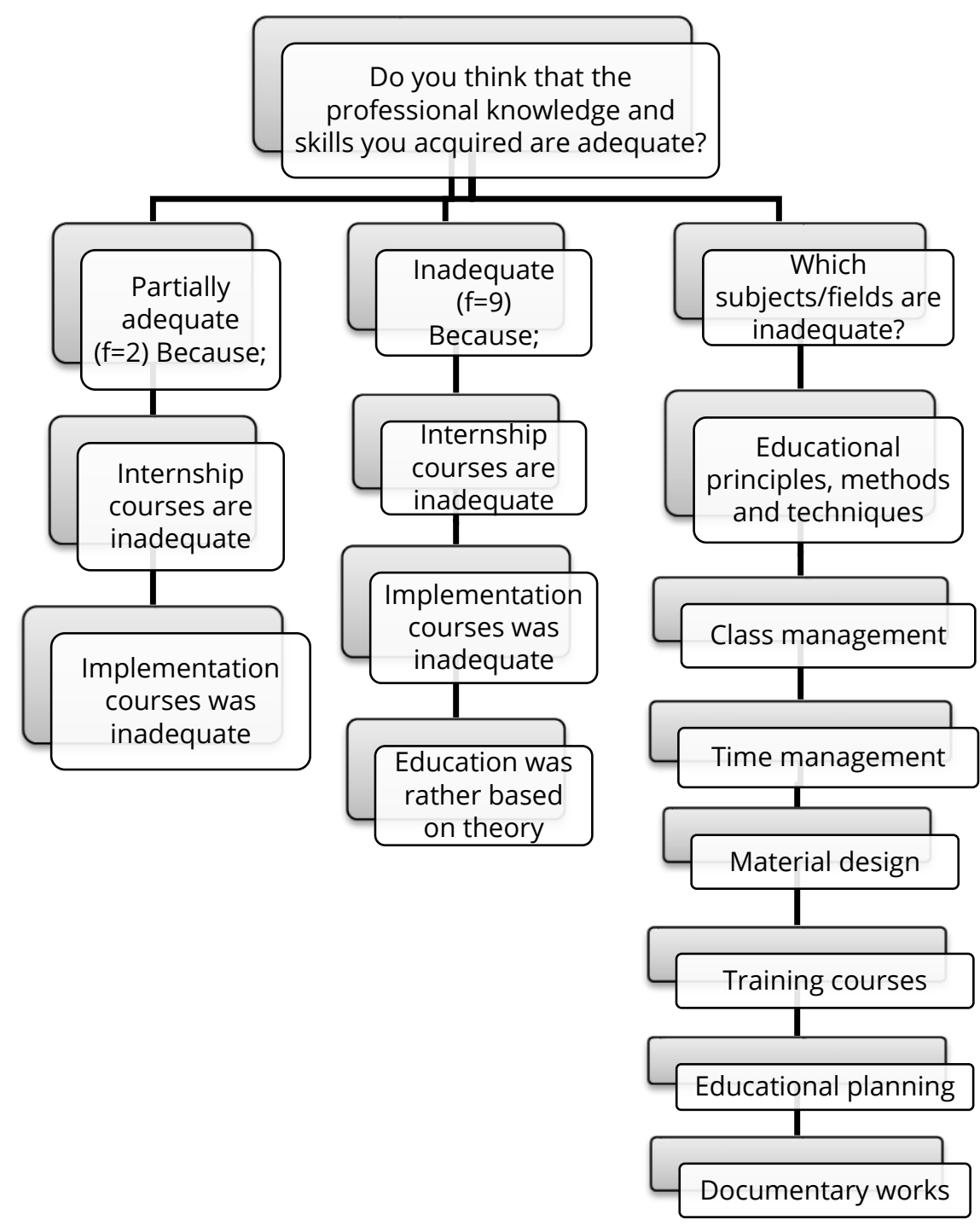

Figure 3. Opinions of novice teachers on the adequacy of undergraduate teacher education they had received.

When we examine Figure 3, we see that 2 of the 11 novice teachers in the research consider the education they had received during their undergraduate teacher education partially adequate in contrast to 9 people who consider it inadequate. Novice teachers who consider it partially adequate have expressed that the training they received in the context of internship and implementation courses in particular was inadequate. Teachers considering their undergraduate teacher education inadequate said that their education was rather based on theory, without an adequate level of application and internship. Primary teachers think that undergraduate teacher education is inadequate particularly in terms of educational principles and methods, class management, time management, material design, training courses, educational planning and document works. Some of the expressions of the primary teachers with regard to the subjects they need 
support for in the first years of their profession are given below:

FT4: Of course not. Because everything was in theory. So on what subjects is it adequate and not? For example I think that I have great deficiency particularly about technical methods of training. I have trouble in material design. Furthermore, I don't think educational courses are that adequate? (...)

MT1: No, I don't think. So on what subjects is it adequate and not? I mean I was particularly thinking about class management. Because there are I guess
20 people, 20 children and you don't know what to do. You should not yell, so I really had troubles. (...)

Findings on the Subjects that require Support

An answer was sought to the question "What are the subjects novice teachers require support in their professional life?" in the fourth sub-problem. The answers of the $11^{\text {th }}$ grade teachers participating in the research to questions were grouped under two themes: (1) Teachers needing Support; (2) teachers not requiring any support (Figure 4).

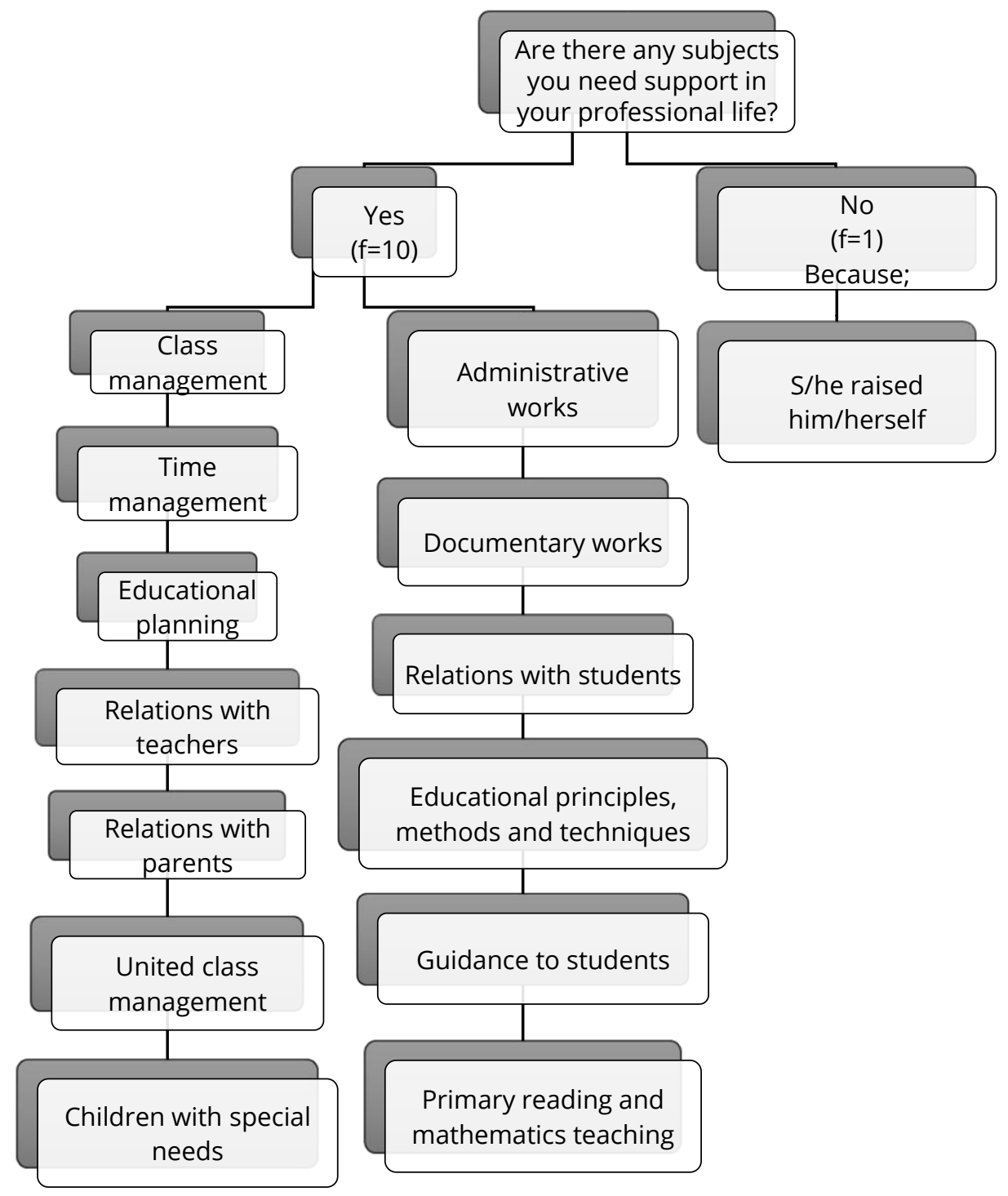

Figure 4. Subjects novice teachers require support for.

An examination of Figure 4 shows that 10 of 11 novice teachers expressed there were subjects s/he needed support in his/her professional life in contrast to 1 who put that s/he needed no support in his/her professional life. The subjects for which novice teachers in $1^{\text {st }}$ to $5^{\text {th }}$ year of his/her job are class management, time management, educational planning, relations with parents, guidance to students, relations with teachers, united class management, educational principles, methods and techniques, primary reading and mathematics teaching, documentary and administrative works. 1 of the novice teachers expressed that s/he needed no support in his/her professional life because $\mathrm{s} /$ he raised him/herself. Some of the expressions of the novice teachers with regard to the subjects they need support for in their professional life are as follows: 
FT5: I had, class management, furthermore, administrative drawbacks (...)

MT2: Now in the first years, your behavior to the students, these are very important. I learnt those myself by experience. Nobody told me about those. For example when I entered the class, when I started to explain the class first, the class ends quickly. It either ended quickly or the bell rang, I could not get it done. (...).

Findings on the Entities and Persons for whom Support is Desired
An answer was sought to the question "From where or by whom do novice teachers require meeting of the subjects they need support in their professional life?" in the fifth sub-problem. The answers of novice teachers to the questions under that sub-problem were grouped under three themes: (1) Those wishing satisfaction of their needed subjects by the Ministry of National Education, (2) those willing their being met by the university, and (3) those meeting them themselves (Figure 5).

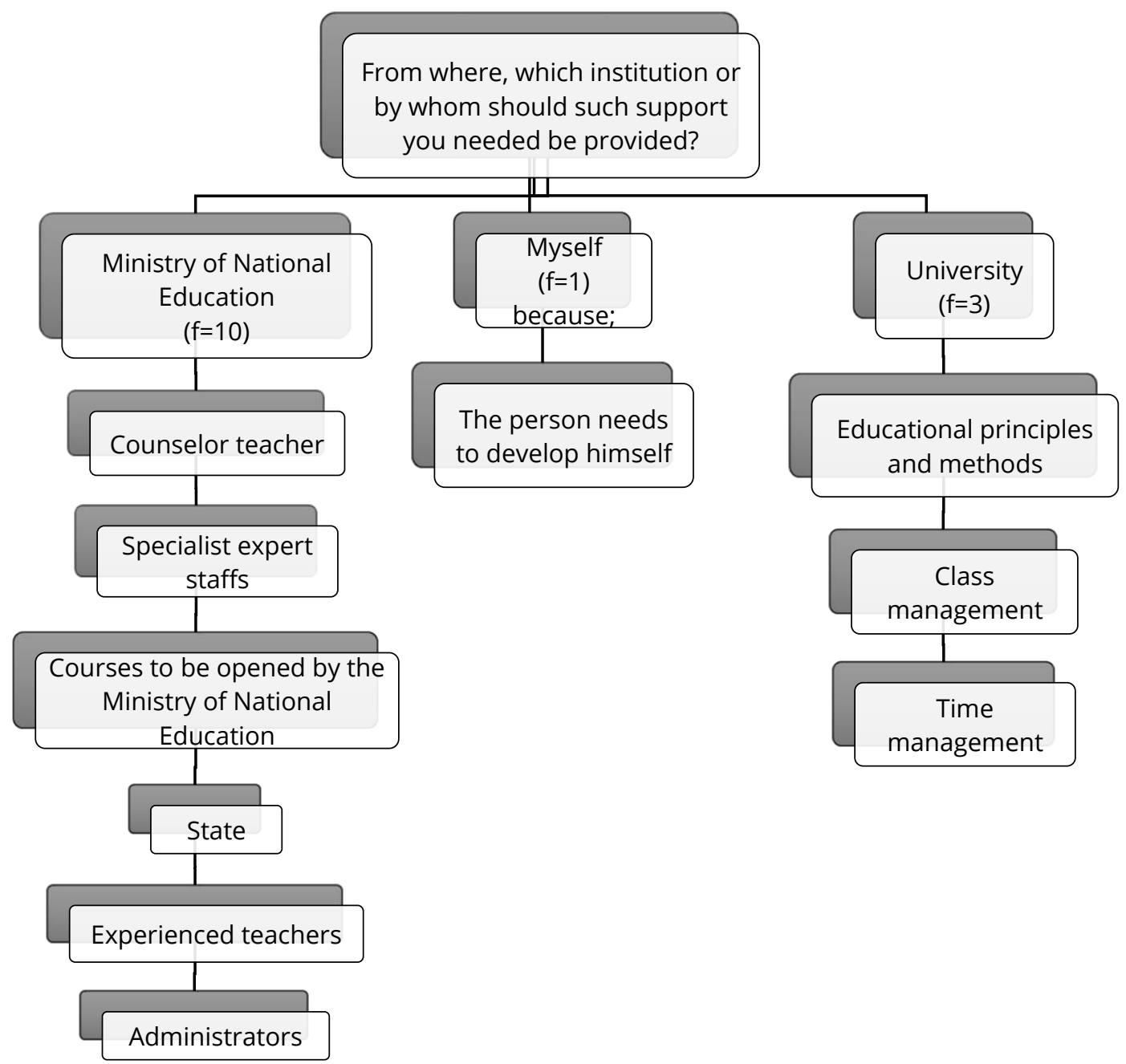

Figure 5. Findings on the entities and persons from whom novice teachers desire support.

10 of the novice teachers ask meeting by the Ministry of National Education of the subjects they need support for in their professional life. Teachers wish meeting of the subjects they feel a need for by guiding teachers on duty in the Ministry of National Education, specialist staff performing their duty in the ministry, courses to be opened by the Ministry of National Education, experienced teachers and administrators (executive). 3 teachers included in the research, however, wish meeting by the universities of the support for the subjects they need. They particularly request meeting of their needs about educational principles, methods and techniques, class management and time management through those entities. 1 of the novice teachers thinks that $\mathrm{s} / \mathrm{he}$ can complete the subjects s/he needs with his/her own efforts.

A few of the answers of the novice teachers to the question "From where and by whom do you wish meeting of the subjects you are in need of support for in your professional life?" are given below: 
MT1: Now it similarly needs to be met by another guiding teacher. When we were first appointed to the job, I thought that a guiding teacher would be assigned, and that intern teacher should not teach classes rather attend for at least a month to the class of the guiding teacher.

FT3: Of course it would be better for us to be taught by people specialized in their fields. For example that may be any university. Or specialist staff formed under, for example, the ministry of science, may help me and people like me.

\section{Findings related to Preservice Teachers}

Findings regarding Adequacy of Undergraduate Teacher Education. An answer was sought to the question "Do undergraduate students find the undergraduate teacher education they received adequate" within the scope of the first sub problem of the research. The answers of the preservice teachers to the questions under that sub-problem were categorized under three themes: (1) Those considering it adequate, (2) those considering it inadequate and (3) subjects considered inadequate

(Figure

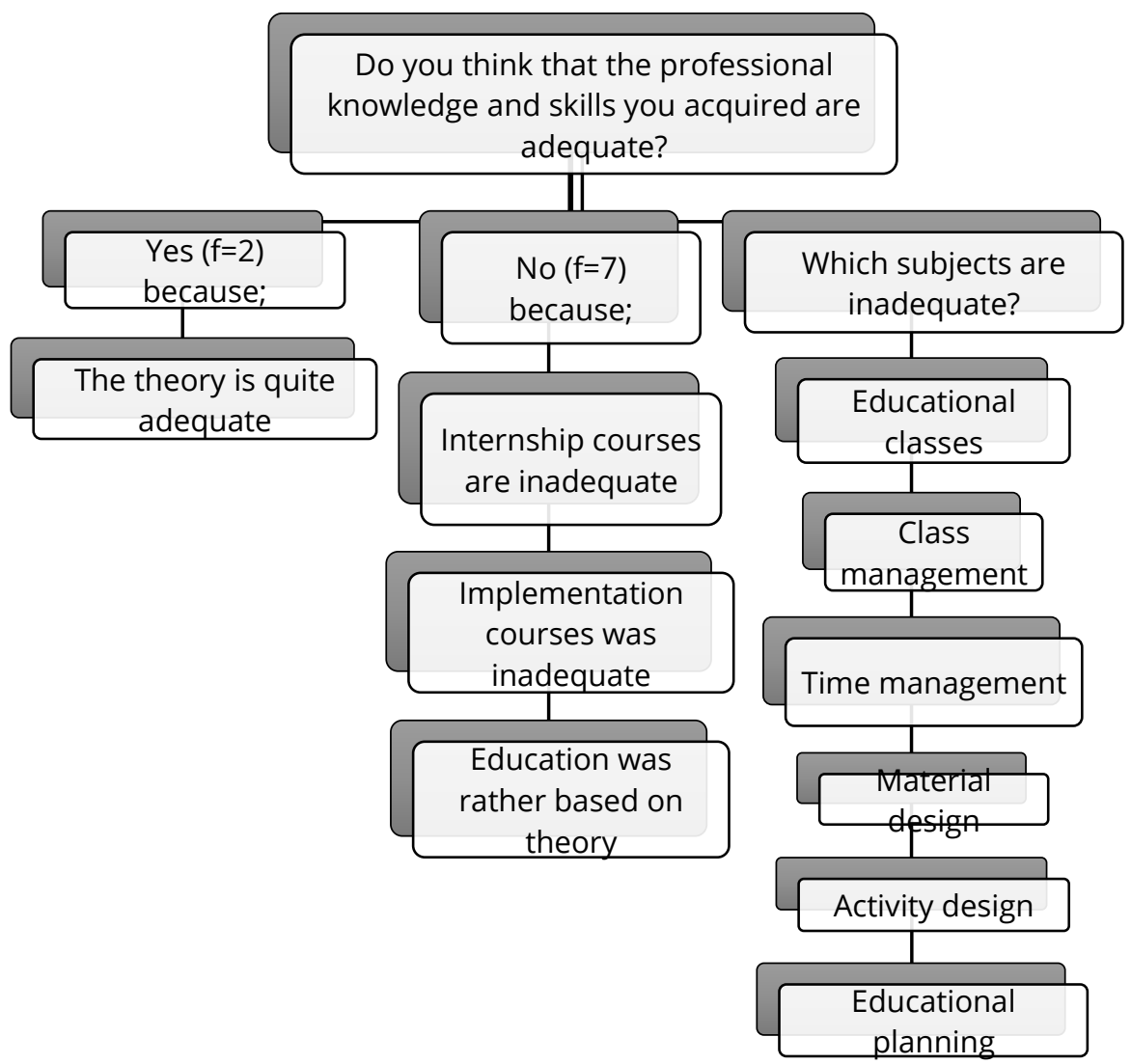

Figure 6. Opinions of the Preservice Teachers on the Adequacy of the Undergraduate Teacher Education.

When we examine Figure 6 , we see that 2 of the 9 preservice teachers consider the undergraduate teacher education they had received adequate in contrast to the 7 who consider it inadequate. 2 of the students find undergraduate teacher education theoretically adequate. Seven of them find undergraduate teacher education inadequate considering that application classes and theory should have had more room. Students think that undergraduate teacher education is inadequate particularly in terms of educational classes, class management, time management, material design, activity design, and educational planning. Some of the expressions of the preservice teachers about the undergraduate teacher education they received are as follows:
MS2: I don't think I have exactly been raised well professionally (...). So about what subjects do you feel missing? Although we study and understand the courses in the school, they are all theoretical. But one thinks how he can do this and that when implementation starts in internship.

FS3: I felt myself more complete after I attended education classes in the third and fourth grades (...) So I think I am sufficient.

Findings on the Subjects that require Support

An answer was sought to the question "On what subjects do the preservice teachers need support?" within the scope of the second sub problem of the research. The answers of the students to the questions under that sub- 


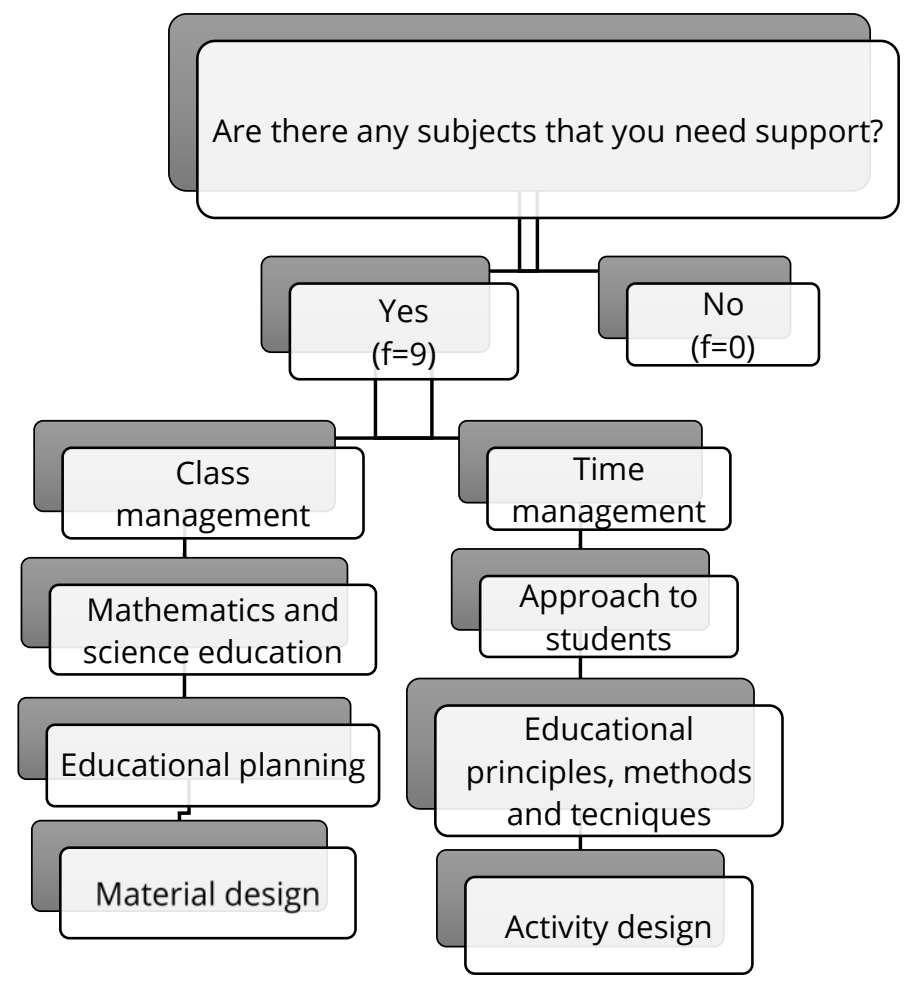

Figure 7. Subjects preservice teachers require guidance for.

When we examine Figure 7, all of the 9 preservice teachers expressed that they had subjects for which they need support. The subjects for which they need Support are class management, time management, mathematics and science education, approach to students, educational planning, educational principles, methods and techniques, material design, activity design. Some of the expressions of the preservice teachers on the subjects on which they require guidance for have been given below:

FS1: Mathematics and science. Because in mathematics lessons, there might actually be high-level problems indeed.

FS4: I currently am insufficient about getting it done in time. They taught us to fully teach a subject within 40 minutes here. They spread it to 10 hours when we went there. We start at once smoothly (...)

\section{Findings on the Subjects that require Support}

An answer was sought for the question "What are the subjects preservice teachers may need support for when they first start their job?" within the scope of the third sub-problem of the research. The answers of the students to the questions under that sub-problem formed two themes: (1) Students to need Support; (2) students to partially need support (Figure 8).

When we examine Figure 8, 7 of the 9 preservice teachers expressed that they had subjects for which they will need support about when they start teaching profession in contrast to 2, who expressed that they will need partial support. The subjects for which students will need support for are mathematics and science teaching, student motivation, time management, student relations, material design, parent relations and activity design. The subjects which students will need support for are feedback to students, activity design and game preparation. Some of the expressions on the subjects preservice teachers will need support/guidance for when they start the job are as follows:

FS2: It may be time planning for example. I think that I cannot fill the class time and but I do. On top of that, for example time doesn't suffice. That kind of trouble happens.

MS2: In other words, let me say. It may be an experience in terms of guidance. Guidance to whom? To students. About which subjects for example? To bring immediate solutions when they have problems. After all we never learned about those.

Findings on the Entities and Persons for whom Support is Desired

An answer was sought to the question "From where or by whom do the preservice teachers desire meeting of the subjects they will need support for in their professional life?" in the fourth sub-problem. The answers of the students to the questions under that sub-problem were categorized under two themes. First, those wishing satisfaction of their needed subjects by the Ministry of 


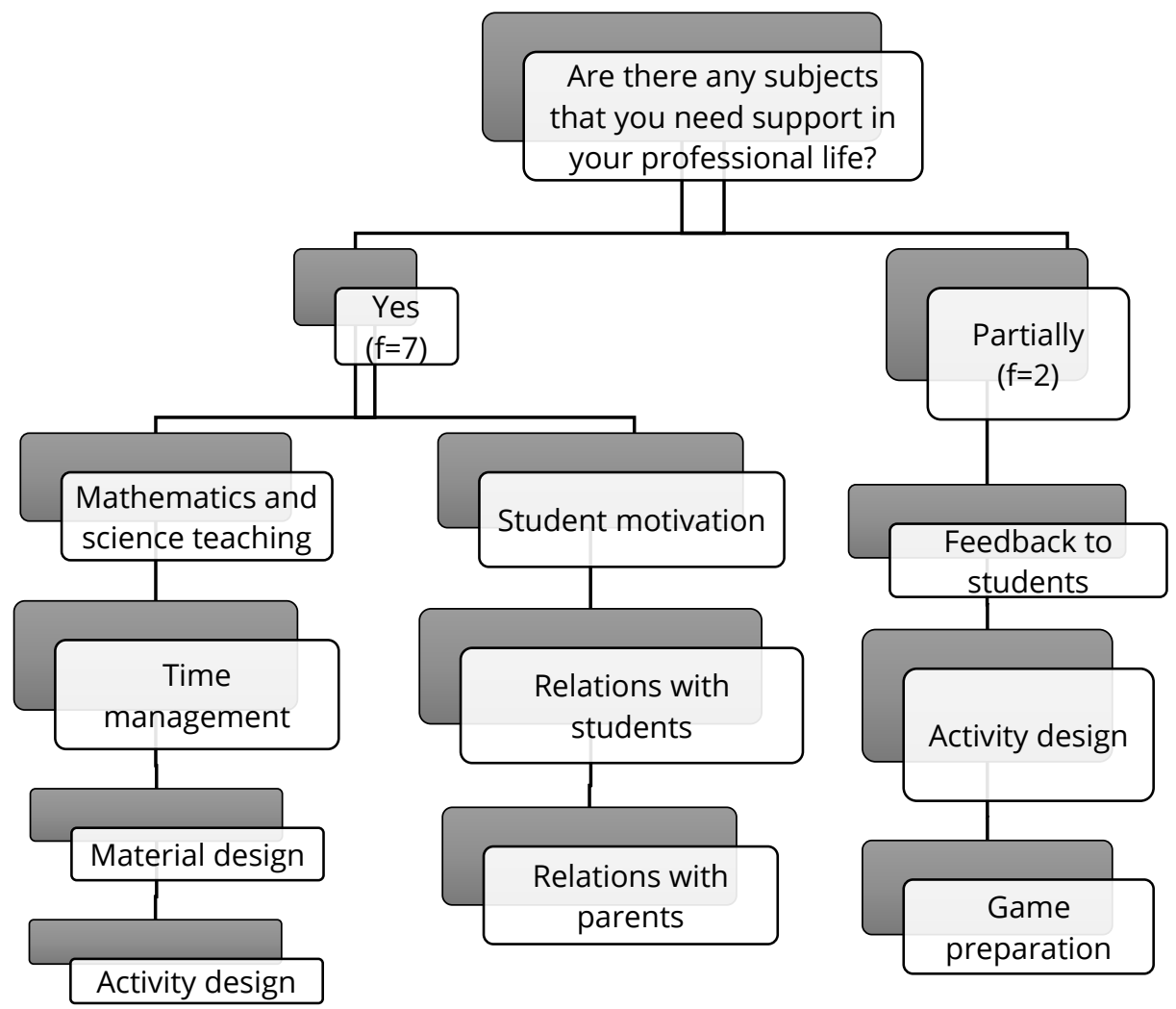

Figure 8. Subjects preservice teachers may need support for.

When we examine Figure 9, 7 of the preservice teachers desire meeting by the Ministry of National Education of the subjects they will need support for in their professional life. Students wish meeting of the subjects they feel a need for by counseling teachers on duty in the Ministry of National Education, specialist staff performing their duty in the ministry, courses to be opened by the Ministry of National Education, experienced teachers. 2 of the students wish meeting of the support for the subjects they need by lecturers in universities from resources to be prepared by the universities. Some of the expressions of the preservice teachers with regard to the entities they desire to meet the subjects they will need support for in their professional life are given below:

MS1: I would like to be informed by more senior teachers about support. Because experienced teachers are almost masters of the job. They can distinguish knowledgeable students just with a look into the eye.

FS3: (...) I would like to be supported by university lecturers, people who investigated the subjects, with some experience at hand.

\section{Discussion and Conclusion}

It is possible to make some deductions considering all findings of the research together. First one relates to the condition of appointment of counselors. According to the finding, mentors were assigned to some of the teachers in contrast to others for whom no mentor assignment was made. Several teachers for whom mentors were assigned got no mentoring service. As a matter of fact, several researches (Afsin, 1998; Korkmaz, 1999; Parlak, 2005) in Turkey show that new teachers of the profession are in general not satisfied with the mentor. This shows that mentoring was not systemized throughout the country in Turkey, that it is not considered in a professional context, and that it is not applied consistently and regularly in a procedural sense. As known, teachers encounter various difficulties and problems in the first years of their job. They mostly feel the need to support or guidance with regard to solution and overcoming of the same for reasons such as inexperience, lack of application etc.. In this context, mentoring is important in terms of a close examination of the problems experienced in the first years of the occupation, overcoming such difficulties, preventing teachers to start the job from suffering similar 


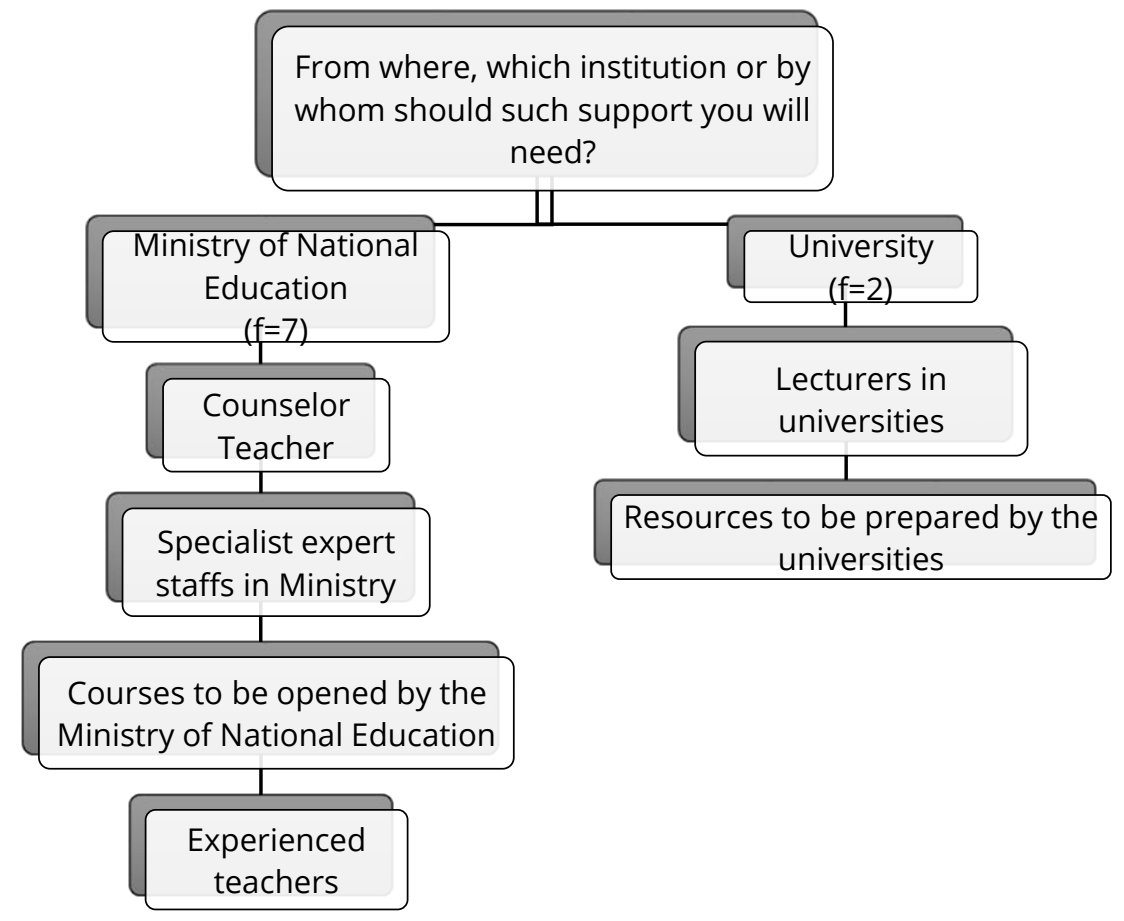

Figure 9. Entities and persons from whom preservice teachers desire support.

Another finding of the research relates to subjects for which novice teachers get counseling service, and subjects they feel the need to counseling services. The shortcomings of novice teachers with and without counseling teachers in matters of "class management, utilization of the class book, administrative works, document works, and approach to students" are common. It is an important case that primary teachers feel short about the field although those are included among the activities of the work plan of the School Experience and Teaching Practice courses and despite the fact that it is an imperative course included in the undergraduate teacher education programmes for class management and class teaching. As a matter of fact, 9 of the 11 novice teachers consider the education they had received during their undergraduate teacher education inadequate in contrast to only 2 people who consider it partially adequate. Novice teachers who consider it partially adequate, however, find that the education they received inadequate particularly in the context of internship and practical courses. Teachers considering their undergraduate teacher education inadequate said that their education was rather based on theory, without an adequate level of practice and internship. Novice teachers think that undergraduate teacher education is inadequate particularly in terms of educational principles and methods, class management, time management, material design, training courses, educational planning and document works. Similarly, 2 of the 9 preservice teachers consider the undergraduate teacher education they had received adequate in contrast to the 7 who consider it inadequate. 2 of the students find undergraduate teacher education theoretically adequate. Seven of them find undergraduate teacher education inadequate considering that internship, practical classes and theory should have had more room. Students think that undergraduate teacher education is inadequate particularly in terms of educational classes, class management, time management, material design, activity design, and educational planning. The finding shows that completing undergraduate teacher education even mostly doesn't mean that the education is over, and especially that both novice and preservice teachers have shortcomings in gaining theoretical knowledge and awareness throughout their undergraduate teacher education and to reflect that on their worlds of value and action, in other words, in establishing an equilibrium among knowledge, values and actions. It also reveals the necessity to conduct practical works to put theoretical knowledge gained through practically available theoretical information into practice throughout the undergraduate teacher education. The finding shows parallelism with some research results too. In the research conducted by Duran, Sezgin \& Coban (2011) teachers having hard time in class management showed inadequate knowledge in the field of teaching occupation as the reason. In a research by Sari \& Altun (2015), it was found out that the professional knowledge and skills of primary teachers just starting the job are not at adequate level due to insufficient experience. Primary teacher candidates who don't find the undergraduate teacher education they had received adequate, according to Çam-Aktas's (2016) research, complain about courses remaining at a theoretical level and few number of the practical courses. Teachers in the first years of their profession express that undergraduate teacher education is more theoretical than practical (Aksoy, 2008; Sari, 2011). No doubt it can be hard for such teachers to find the possibility to develop themselves for reasons such as the fact that teachers just starting the job in Turkey mostly work in schools with 
poor conditions, that there are inequalities in distribution of experienced teachers to schools etc. In this context of mentoring, although not the cure for all problems teachers experience, cannot be denied as an effective solution alternative in that mentoring provides adequate field and pedagogy knowledge and presents professional support. Moreover, the professional benefit and positive effect of mentoring both for the mentor and the mentee have been revealed by several researchers (Tang \& Choi 2005, Zachary 2009).

Another important finding of the research is that there are subjects for which 10 of the 11 novice teachers in 1st to 5th year of their job need support for, and that these consist of the subjects of class management, time management, educational planning, relations with parents, guidance to students, relations with teachers, united class management, educational principles, methods and techniques, primary reading and mathematics teaching, documentary and administrative works. There is also a similar case in preservice teachers. All of the preservice teachers, particularly need support on the subjects of "class management, time management, mathematics and science education, approach to students, educational planning, educational principles, methods and techniques, material design, activity design". 7 of the preservice teachers express that they have subjects for which they will need support about when they start teaching profession in contrast to 2, who express that they will need partial support. The students particularly indicate that they will need support for the subjects of "mathematics and science teaching, student motivation, time management, student relations, material design, parent relations and activity design"; and that they will need partial support on the subjects of "feedback, activity design and game preparation".

A view of the subjects for which novice and preservice teachers need support shows that they have serious shortcomings in the context of theory and practice. It should be considered what kind of ambiance would be formed in the classroom by a teacher appearing or a candidate teacher to possibly appear before the students with such shortcomings, to what extent s/he may be useful to students, how much willing and determination s/he can perform his/her duty, how much satisfaction s/he can get from the profession and what kind of mood and motivation would primary school children face. It is imperative to ponder that especially considering the fact that being useful to the society and children (EBSAM, 2010) ranks high in Turkey as a motivation of the candidate teachers in choosing the profession.

Another important finding of the research is that 10 of the 11 novice teachers think of meeting of such subjects that they feel a need for by counseling teachers on duty in the Ministry of National Education, specialist staff performing their duty in the ministry, courses to be opened by the Ministry of National Education, experienced teachers and administrators (executive). 3 of the teachers find more convenient that the support on "educational principles, methods and techniques, class management and time management" be provided by universities. 7 of the preservice teachers desire meeting of the subjects they will feel a need for by counseling in their professional life be met by counseling teachers on duty in the Ministry of National Education, specialist staff performing their duty in the ministry, courses to be opened by the Ministry of National Education, experienced teachers. 2 of the students wish meeting of the support for the subjects they need by lecturers in universities from resources to be prepared by the universities.

Katz (1995) examines the career process in teacher under four stages of development: (1) Survival, (2) consolidation, (3) renewal, (4) maturity. At survival stage, teachers focus on themselves and their own needs, with little interest in the students and understanding their needs. They take no responsibility about what's happening in the classroom. Consequently, the need of the teachers for support, understanding, encouraging, trust, opinion support and counseling is evident at that stage. At the stage of consolidation, guidance in place for special educational skills and meeting individual and group needs of the students are significant. At this stage, teachers start focusing on education and the separate learning needs of each student. They investigate the ways to cope with students with trouble understanding, experiencing disciplinary problems etc.. At the third stage, teachers start mastering teaching; and dominating the management and teaching strategies. They start looking for new things to provide variety in teaching practices. They always try to improve the class and their students. At maturity, which is the ultimate stage, teachers continue being interested in new ideas and resources. They ask rooted questions to themselves about the children and the arts of teaching. Teachers at that stage can be good mentors each. Because they had experienced all development stages of teaching, and have solved/understood what teachers need in the first three stages. If research findings are evaluated in this context, it would be more convenient to provide the professional support needed by the new teachers of the profession at the hands of experienced teachers at the maturity stage of the profession. Considering the significance of immediate accessibility by the mentee of the mentor, it is even clearer that mentoring service should be provided by experienced teachers. As a matter of fact, in a research conducted by Moyles, Suschitsky \& Chapman (1999), participants found accessibility of the mentor highly important.

It is possible to discuss the findings of the research generally under two contexts. First one is that both novice and preservice teachers actually in service have shortcomings both in gaining, interiorizing theoretical knowledge and reflecting that in their world of action. The second issue that can be considered as both a reason and outcome of that relates to development of a perspective with a focus on skills and competence in raising teachers. It is not in vain that Bloom has made a triple classification as "cognitive, affective, psychomotor" in educational objectives and targets. Also it is not surprising that one of the most important theses of Dewey with regard to pedagogy is experience, learning by action and living. It is extremely important to conduct practical works in schools, to personally experience classroom environment and to put in practical use what has been learnt for 
raising qualified teachers. In this context, it is a necessary and urgent need to see mentoring system as a positive experience and to systemize it in Turkey in the field of training teachers. Such support for the new teachers of the profession in Turkey, a country including thousands of teachers to the system every year, is extremely important. As a matter of fact, there is a consensus among researchers that mentoring contributes to success and gaining of knowledge, provides emotional and psychological support, is mutual, intrinsically personal, shows experience and success of the mentor in the process (Schmidt \& Faber, 2016: 141).

\section{References}

Afsin, F.N. (1988). Stajyer ogretmenlerin meslekle ilgili sorunlar ve cozum yollari. Yayinlanmamis Yuksek Lisans Tezi, Hacettepe Universitesi Sosyal Bilimleri Enstitusu, Ankara.

Aksoy, N. (2008). Birlestirilmis siniflarda egitim-ogretim: genc ve deneyimsiz ogretmenlerin goruslerine dayali bir arastirma. Egitim Bilim ve Toplum Dergisi, 6(21), 82-108.

Bakioglu, A. (Edt.) (2015). Egitimde mentorluk. 3. Baski, Ankara: Nobel Yayincilik.

Buell, C. (2004). Models of mentoring in communication. Communication Education, 53(1): 56-73.

Cam-Aktas, B. (2016). Sinif ogretmeni adaylarinin mesleki yasamlarında karsilabileceklerini dusundukleri sorunlar. Mehmet Akif Ersoy Universitesi Egitim Fakultesi Dergisi, 38, 16-30.

Dağ, N. (2011). Beynin ve noronun yapisi ve fonksiyonu ile beyin arastirmalari tarihine kisa bir bakis. EKEV Akademi Dergisi, 15(47), 1-18.

Duran, E., Sezgin, F., \& Coban, O. (2011). Aday sinif ogretmenlerinin uyum ve sosyallesme surecinin incelenmesi. Dumlupinar Universitesi Sosyal Bilimler Dergisi, 31, 465-478.

EBSAM (2010) EBSAM Arastirmalari 1. Ankara: Eğitim-BirSen Stratejik Arastirmalar Merkezi.

Ginkel, G.V., Verloop, N., \& Denessen, E. (2015). Why mentor? linking mentor teachers'motivations to their mentoring conceptions. Teachers and Teaching: Theory and Practice, 1-16.

Hudson, P. (2013). Strategies for mentoring pedagocial knowledge. Teachers and Teaching: Theory and Practice, 19(4): 363-381.

Katz, L.G. (1995). Talks with teachers of young children: A collection, Stamford, CT: Ablex.

Korkmaz, S. (1999). Goreve yeni baslayan ogretmenlerin meslege uyum sorunlari. Yayinlanmamis Yuksek Lisans Tezi. Kocaeli Universitesi, Sosyal Bilimler Enstitusu, Kocaeli.

Lehsem, S. (2014). How do teachers mentors perceive their role, does it matter? Asia-Pasific Journal Teacher of Education, 42(3), 261-274.
Miles, M, B., \& Huberman, A. M. (1994). Qualitative data analysis: An expanded Sourcebook. (2nd ed). Thousand Oaks, CA: Sage.

Moyles, J., Suschitsky W., \& Chapman, L. (1999). Mentoring in primary schools: Ethos, structures and workloads. Journal of In-Service Education, 25(1), 161-172.

Nasser-Abu Alhija, F., \& Fresko, B. (2014). An exploration of the relationships between mentor recruitment, the implementation of mentoring, and mentors'attitudes. Mentoring \& Tutoring: Partnership in Learning, 22(2), 162-180.

Parlak, C. (2005). Stajyer ogretmenlerin formal ve informal sosyalizasyon surecleri (Igdır lli Ornegi). Yayinlanmamis Yuksek Lisans Tezi, Gazi Universitesi Egitim Bilimleri Enstitusu, Ankara.

Sari, M.H. (2011). Göreve yeni başlayan sınıf öğretmenlerinin karşılaştıkları sorunlar. Yayinlanmamis Yuksek Lisans Tezi, Gazi Universitesi Egitim Bilimleri Enstitusu, Ankara.

Sari, M.H., \& Altun, Y. (2015). Göreve yeni başlayan sınıf öğretmenlerinin karşılaştıkları sorunlar. Hacettepe Universitesi Egitim Fakultesi Dergisi, 30(1), 213226.

Schmidt, E.K., \& Faber, S.T. (2016). Benefits of peer mentoring to mentors, female mentees and higher education institutions. Mentoring \& Tutoring: Partnership in Learning, 24(2), 137-157.

Searby, L., \& Tripses, J. (2012). Etkili mentorlar olabilmeleri için okul liderlerini hazirlama (s. 1-19). Dunyada mentorluk uygulamalari, Edt.: R. Yirci ve i. Kocabas, Ankara: PegemA Yayinlari.

Tang, S.Y.F., \& Choi, P.L. (2005). Connecting theory and practice in mentor preparation: Mentoring for the improvement of teaching and learning. Mentoring and Tutoring, 13(3), 383-401.

Veenman, S. (1984). Perceived problems of beginning teachers. Review of Educational Research, 54(2), 143-178.

Yildirim, A., \& Simsek, H. (2008) Sosyal bilimlerde nitel arastirma yontemleri [Qualitative Research Methods in Social Sciences]. Guncellestirilmis Gelistirilmis 6. Baski, Ankara: Seckin Yayinlari.

Zachary, L. (2009). Examining and expanding mentoring practice. Adult Learning, 20(1-2), 43-45. 
This page is intentionally left blank www.iejee.com 